\title{
An easy-to-manage two-entrance honey bee hive system for greenhouse pollination that improves fruit production
}

\author{
Sistema prático de manejo de colmeias com duas entradas para abelhas melíferas para polinização \\ em casa de vegetação que incrementa produção de frutos \\ Práctico sistema de manejo de colmenas con dos entradas para abejas melíferas para polinización \\ en invernadero que aumenta la producción de frutas
}

Received: 08/30/2021 | Reviewed: 09/04/2021 | Accept: 08/09/2021 | Published: 09/11/2021

Beatriz de Jesus Rodrigues

ORCID: https://orcid.org/0000-0002-8828-3353

Universidade Estadual Paulista, Brazil

E-mail: beatrizrodrigues359@gmail.com

Omar Jorge Sabbag

ORCID: https://orcid.org/0000-0003-3940-4240

Universidade Estadual Paulista, Brazil

E-mail: omar.sabbag@unesp.br

Gustavo do Valle Polycarpo

ORCID: https://orcid.org/0000-0001-6282-3297

Universidade Estadual Paulista, Brazil

E-mail: gustavo.polycarpo@unesp.br

David De Jong

ORCID: https://orcid.org/0000-0003-2131-9988

Universidade de São Paulo, Brazil E-mail: ddjong@fmrp.usp.br

Daniel Nicodemo

ORCID: https://orcid.org/0000-0001-6594-5791

Universidade Estadual Paulista, Brazil

E-mail: daniel.nicodemo@unesp.br

\begin{abstract}
An alternative two-entrance hive system demonstrated here is less taxing for the bee colonies. Bees are directed to forage inside the greenhouse when the crop is in flower, and only have access to the outside after anthesis. Consequently, there are no bees in the greenhouse in the afternoon, facilitating crop management. This system allows the farmer to control bee access to the crop without the need for a smoker or protective equipment. Using this system, we compared pollination by honey bees (Apis mellifera) to hand pollination of zucchini squash (Cucurbita pepo) in greenhouses, during two crop seasons. Data included number of flower visits by the bees, fruit production, and the time and consequent labor costs needed to control bee flight direction versus the costs of hand pollination. In the greenhouses with bees, each female flower received a mean of more than 40 bee visits. When eight or more bees visited a flower, the fruits were significantly heavier than with manual pollination ( 313 versus $232 \mathrm{~g}$, respectively). Total production was increased $41 \%$ with bee pollination. Using bee pollination increased profit over $12 \%$, taking into account hive rental and labor costs for hand pollination versus manipulating the hive entrances.
\end{abstract}

Keywords: Cucurbitaceae; Production cost; Honey bees; Fruit set; Profit margins.

\section{Resumo}

Um sistema alternativo de colmeia com duas entradas demonstrado aqui é menos estressante para as colônias de abelhas melíferas. As abelhas são direcionadas para forragear dentro da estufa agrícola quando a cultura está com as flores abertas e são direcionadas diariamente ao exterior após a antese. Consequentemente, não há abelhas na estufa no período da tarde, facilitando o manejo da cultura. Este sistema permite que o agricultor controle o acesso das abelhas à cultura sem a necessidade de um fumegador ou vestimenta apícola. Utilizando esse sistema, comparamos a polinização por abelhas melíferas (Apis mellifera) com a polinização manual da abobrinha (Cucurbita pepo) em estufas, durante duas safras. Nós verificamos o número de visitas das abelhas às flores, a produção de frutos e o tempo e os custos de mão-de-obra necessários para controlar a direção do voo das abelhas em comparação aos custos da polinização manual. Nas estufas com abelhas, cada flor feminina recebeu em média mais de 40 visitas de abelhas. Quando oito ou mais abelhas visitaram uma flor, os frutos foram significativamente mais pesados do que com a polinização manual (313 x $232 \mathrm{~g}$, respectivamente). A produção total aumentou $41 \%$ com a polinização por abelhas. O uso da polinização por abelhas aumentou o lucro em mais de $12 \%$, levando em consideração o aluguel da colmeia e os 
custos de mão-de-obra para a polinização manual em comparação com a manipulação das entradas da colmeia. Palavras-chave: Abelhas melíferas; Cucurbitaceae; Custo de produção; Frutificação; Margens de lucro.

\section{Resumen}

Un sistema alternativo de colmena de dos entradas demostrado aquí es menos estresante para las colonias de abejas. Las abejas se dirigen a forrajear dentro del invernadero agrícola cuando el cultivo tiene flores abiertas y se dirigen al exterior diariamente después de la antesis. En consecuencia, no hay abejas en el invernadero por la tarde, lo que facilita el manejo del cultivo. Este sistema permite al agricultor controlar el acceso de las abejas al cultivo sin necesidad de un ahumador o ropa de apicultura. Utilizando este sistema, comparamos la polinización de abejas melíferas (Apis mellifera) con la polinización manual de calabacín (Cucurbita pepo) en invernaderos, durante dos temporadas. Observamos el número de visitas de las abejas a las flores, la producción de frutas y los costos de tiempo y mano de obra necesarios para controlar la dirección de vuelo de las abejas en comparación con los costos de la polinización manual. En invernaderos con abejas, cada flor hembra recibió un promedio de más de 40 visitas de abejas. Cuando ocho o más abejas visitaron una flor, los frutos fueron significativamente más pesados que con la polinización manual ( 313 x 232 g, respectivamente). La producción total aumentó en un $41 \%$ con la polinización de las abejas. El uso de la polinización de abejas aumentó la ganancia en más de un 12\%, teniendo en cuenta el alquiler de la colmena y los costos de mano de obra para la polinización manual en comparación con el manejo de las entradas de la colmena.

Palabras clave: Abejas melíferas; Cucurbitaceae; Costo de producción; Fructificación; Márgenes de beneficio.

\section{Introduction}

Zucchini squash (Cucurbita pepo) is a cucurbit that originated in the Americas and that has been selected and grown for thousands of years; it is a common vegetable for human consumption in many regions of the world. This plant is also called Italian zucchini, due to its popularity in Italy, where it is widely used due to its versatility in culinary use and high nutritional value (Whitaker \& Bemis 1975; Decker, 1988; Rouphael et al., 2004).

Zucchini plants are annuals and monoecious, having separate pistillate and staminate flowers, which are attractive to bees because of the abundance of floral resources that they offer to flower visitors (Free, 1993). Fruit production by zucchini plants requires visits by pollinating agents to transport pollen to the stigmas (Fischer et al., 2012). This crop requires insect pollination in order to provide a satisfactory harvest; if insect pollinators are not available, $90 \%$ or more of the potential fruit production can be lost (Giannini et al., 2015). Honey bees are efficient pollinators of many crops, as their foraging for both nectar and pollen increases the chance of transferring pollen from flower to flower (D'avila \& Marchini, 2005).

In open fields, insects have free access to the flowers, and various visits by different species are possible (Pfister et al., 2017). If at least one of these species is an effective pollinator for this crop and if this species makes several flower visits, there can be satisfactory production of cucurbit fruits (Nepi \& Pacini, 1993; Nicodemo et al., 2009). However, various environmental factors can influence the production of this group of plants (Adams et al., 2008).

Since open field plantings are difficult to control, production in closed environments has become more and more common, as it allows temperature control in the crop microenvironment, better efficiency and precision in the amount of water made available to the plants by irrigation, and improved control of pests and diseases, resulting in increased production and better quality plant products (van Straten et al., 2010). Consequently, producing zucchini in a protected environment is a useful option for horticulturists, increasing the probability of favorable profit margins (Couto et al., 2009).

In order to make zucchini production in greenhouses viable, some strategies have been developed to allow fruit production without the need for bees. One of these alternatives is hand pollination, collecting viable pollen from flowers and distributing these male gametes to pistillate flowers in anthesis, accomplishing fecundation in order to produce fruits (Stone et al., 1995). This method can guarantee good production levels; however, it results in considerable additional production costs (Allsopp et al., 2008; Fischer et al., 2012). Consequently, this alternative should be carefully evaluated, considering that using bees for pollination could be less expensive and potentially easier to implement (Hill et al., 2019). 
Keeping bees in a greenhouse can be quite stressful, so that beekeepers are reluctant to provide bees, as they have found that their colonies will be considerably weakened within a short time in these closed environments. An option using hives that can be directed alternatively to forage inside and outside the greenhouse has been developed, though it requires daily manipulations (Nicodemo et al., 2018). An advantage to this pollination system that effectively reduces costs for the beekeeper and the squash farmer is that bee colonies managed in this way are much less stressed and damaged than if they were confined within the greenhouse. We decided to test this type of hive for greenhouse zucchini pollination, comparing costs and fruit production results with the hand pollination alternative that is currently recommended and widely used (Cardoso, 2005; Romano et al., 2008).

\section{Methodology}

\subsection{Details of the greenhouse, planting, crop management, and climate}

Zucchini squash (Cucurbita pepo) cultivar Alícia/SAKATA was planted from seed in May and September 2019. After 15 days in a greenhouse, the seedlings were transplanted to the soil with $1.3 \times 0.6 \mathrm{~m}$ spacing (130 plants per greenhouse) in

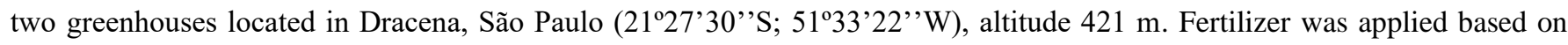
soil analysis and the recommendations for squash crops in São Paulo state (Raij et al., 1996).

During flowering and fruit production, climate data was recorded, including temperature, relative humidity, solar radiation and evapotranspiration.

\subsection{Greenhouses and two-entrance hives}

The hoop type greenhouses measured $15 \times 7 \mathrm{~m}$ and $3.2 \mathrm{~m}$ high. They were covered overhead with agricultural low density polyethylene film with UV blocking and laterally with 50\% sunblock shade netting). On the side of one of the greenhouses, an opening at a height of $1.4 \mathrm{~m}$ was made in the shade netting to accommodate a two-entrance beehive; one entrance was for access to inside the greenhouse and the other to the outside (Figure 1).

Figure 1. Two entrance five-frame standard Langstroth honey bee hive installed in a screened side of the greenhouse with the entrance to the outside closed. The round opening leads to a screen funnel inside the hive directed to a space under a middle shallow Langstroth frame, so that bees can return home but cannot exit through this second entrance.

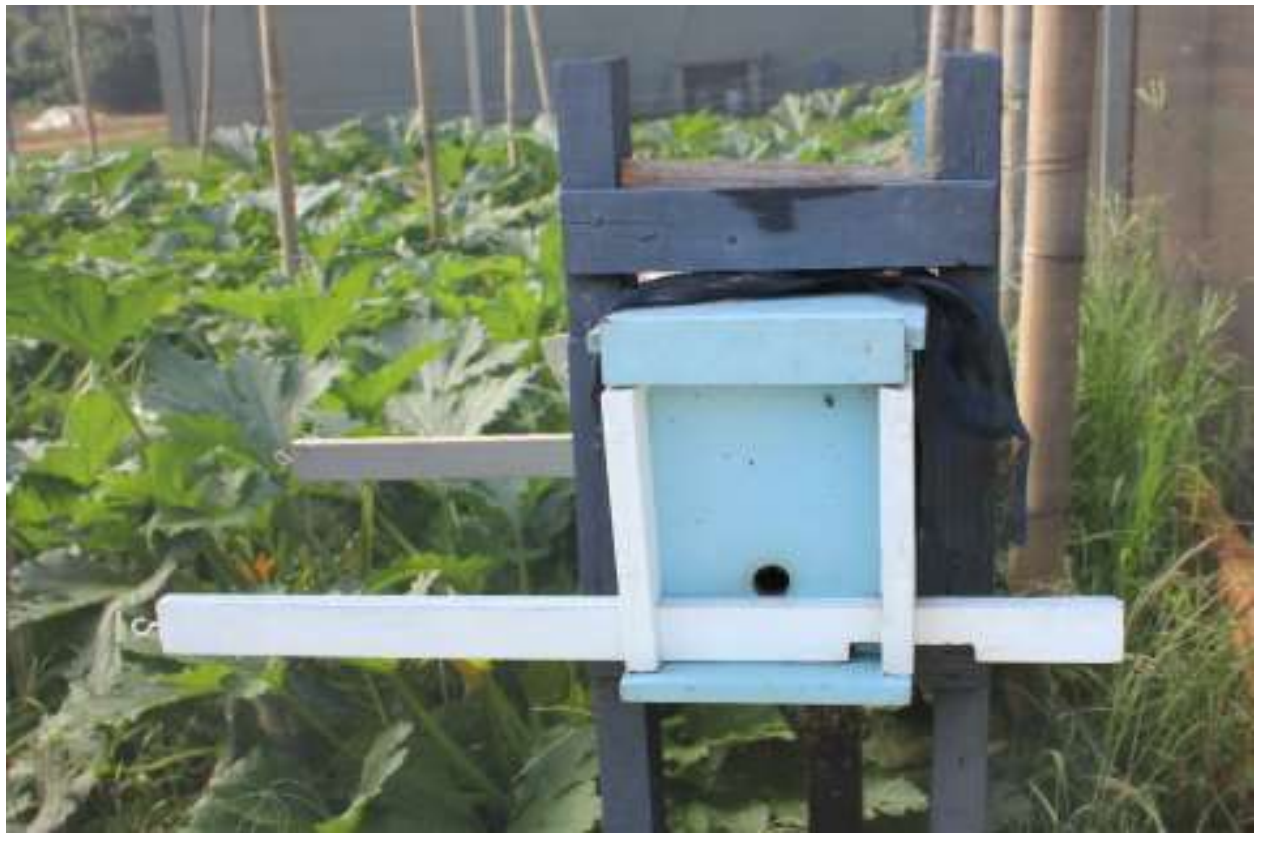

Source: Authors. 
The two-entrance hive was an adaptation of a hive developed by Nicodemo et al. (2018), with alterations to facilitate opening and closing the entrances (Figure 1), to allow someone without beekeeping experience to control where the bees could forage without needing to use a veil or bee suit or a beekeeping smoker. The hives can be opened and closed at each end by sliding an entrance blocker. When an entrance is blocked, the bees can still return to the hive through a one-way screen cone embedded in the hive.

In the greenhouse that had a two-entrance hive attached, only the entrance to inside the greenhouse was opened early in the day, so that the honey bees had access to the squash plants from 08:00 to 12:00 during the fall/winter crop season and from 05:00 to 10:00 during the spring crop season. During the rest of the day, the bees were only able to fly to the outside.

In both crop seasons, a second greenhouse containing squash plants (without bees) was hand pollinated. Every day during the flowering period, pollen from two staminate flowers was used to pollinate each pistillate flower. The staminate flowers were removed from the plant, and their petals cut off to expose the stamens, which were placed into contact with the stigmas in the pistillate flowers, so that pollen grains were transferred (Cardoso, 2005; Romano et al., 2008).

\subsection{Data on the flower biology of the zucchini squash}

The floral biology of the zucchini squash plants was examined to compare the effects of the different pollination techniques (manual versus bee pollination) and how it affected fruit production and to determine if the flower conditions in each greenhouse and season were comparable.

Flower production was recorded for three squash plants in each greenhouse. After the daily counts, the flowers were removed from these plants. Anthesis was followed for 30 marked flowers in each greenhouse on three different days, for a total of 90 flowers per greenhouse, examining equal proportions of staminate and pistillate flowers.

Pollen production was measured for 10 flowers in each greenhouse during three days for a total of 30 flowers per greenhouse. The flowers were selected at random and protected with a fine veil bag before opening, so that bees could not visit. After anthesis, the flowers were uncovered, and the anthers collected and placed individually in Eppendorf tubes containing $70 \%$ ethanol. The pollen was left to settle for 24 hours. The supernatant was then removed with a pipette and $5 \mathrm{ml}$ of $50 \%$ glycerol added to the pollen pellet. The tubes were vortexed until a uniform suspension of the pollen grains was obtained. Five $50 \mu \mathrm{L}$ samples of the suspension were collected from each tube to make counts under a microscope with a magnification of 60X (Nicodemo et al., 2007).

Pollen viability was evaluated on three different days in both greenhouses. On the day before each evaluation, six staminate flower buds were randomly chosen and covered with fine veil bags. The next day, half of the flowers were analyzed at 8:00 and the other half at 12:00 noon. The pollen grains were removed from the stigmas with a fine paint brush and placed on glass slides. Then three drops of Alexander's triple solution were placed on the pollen grains (Alexander 1969) and they were covered with a coverslip so that they could be analyzed with a microscope (Nicodemo et al., 2007).

The receptivity of the stigma was evaluated on three different days, with 10 pistillate flowers analyzed per day in each greenhouse, half of which were analyzed at 08:00 and the other half at 12:00, for a total of 30 flowers per greenhouse. A few drops of $6 \%$ hydrogen peroxide (20 volumes) were placed on the stigmas, and they were analyzed with a stereomicroscope to observe the intensity of the bubbling, which indicates the receptivity of the stigma for the pollen grains (King, 1960). A qualitative comparative analysis was made of the bubbling, dividing the emission of bubbles by the stigmas into three levels, with "low" for few bubbles, "high" for vigorous bubbling and "medium" for an intermediate level of bubbling. 


\subsection{Study of the foraging behavior of the honey bees on the squash flowers}

For each experiment, a week before placing the hive in the screened side wall of the greenhouse, the colony population was standardized. Each five-frame hive contained four standard deep Langstroth frames of bees, one with young brood, two with sealed brood and one containing honey and pollen. The central frame in each hive was a shallow standard Langstroth frame containing brood, honey and stored pollen, to leave space under the frame for the screen funnel for returning bees from the field or the greenhouse, when the corresponding entrance was blocked (Nicodemo et al., 2018).

During each of the crop seasons, the frequency of bee visits to pistillate flowers was measured on six nonconsecutive days for the previously marked plants. The number of bee visits was registered from the beginning to the end of the bee activity periods.

\subsection{Effect of pollination and zucchini squash fruit production}

In the greenhouse with bees, 100 pistillate flowers were marked. Among these, 20 pistillate flowers were left open for bee visits; another 20 were constantly covered during anthesis with a fine mesh cloth bag. Three additional groups of flowers were covered with a fine mesh cloth bag after they had received two, four or eight bee visits (Delaplane et al., 2015).

In the greenhouse without bees, 20 pistillate flowers were marked and were not pollinated manually to determine if they would still produce fruit. Another 20 flowers that were manually pollinated were also marked. This was repeated for the fall/winter and spring crop seasons. A week after anthesis, whether fruit formation began was registered for each marked flower. After the fruits had been fully formed, they were harvested and weighed.

\subsection{Determination of the time needed per day for manual pollination and for manipulating the hive entrances in the greenhouses, including estimated costs.}

The time needed for manual pollination was registered daily during the entire flowering period, along with the number of pistillate flowers that were pollinated. The time needed daily to open and close the hive entrances to direct the bees to the inside of the greenhouse or to the outside was also registered during the entire flowering period.

For each of these greenhouses, the cost per unit of hand labor was calculated based on the monthly salary in 2020 of a farm worker for the region of Presidente Prudente, São Paulo State (US\$387.60), divided by 24 work days (192 hours), using the methodology of the Agronomic Economics Institute of the state of São Paulo (Matsunaga et al., 1976). This was used to determine the total cost of labor for each pollination system.

A value of US\$ 9.04, a typical fee in this region to rent hives with 10 five standard Langstroth frames) was used to indicate the cost of providing bees for pollination for approximately six weeks. Though we used five frame hives compared to the 10 frame hives that are normally rented for this price, the difference in cost would be compensated by the necessity to make modifications to the hive and to the greenhouse to insert the hive.

The gross income was calculated based on the value of the crop, multiplying the weight of the harvested squash by the mean price that growers get from the main distribution center in their region, which is CEASA-Campinas. Then the operational profit (OP) was determined based on the difference between the gross income (GI) and the production costs. The profitability ratio (PR) was determined by dividing the operational profit by the gross income and multiplying by 100 to get a percentage: $\mathrm{PR}=(\mathrm{OP} / \mathrm{GI}) \times 100$ (Martin et al., 1997).

\subsection{Statistical Analyses}

The Statistical Analysis System software (SAS Institute, 2020) was used, considering 5\% as the significance cut-off. The quantitative variables were examined using analysis of variance (ANOVA). For the variables number of staminate and 
pistillate flowers, anthesis, production of pollen grains per flower and mean time needed for hand pollination and for manipulating the hive entrances to direct bees to forage inside or outside the greenhouse, a $2 \times 2$ factorial scheme was considered, with two greenhouses (bees and hand pollination) evaluated in two seasons (fall/winter and spring). For the variable viability of pollen grains, a 2 × 2 × 2 factorial scheme was used, which considered, in addition to the effects already mentioned, the effect of two different times (8:00 and 12:00). The fruit weight was studied under a $2 \times 5$ factorial scheme, with two seasons (fall/winter and spring) and five types of pollination (2, 4, 8 bee visits per flower, freely visited and hand pollinated flowers). When significant effects were found, the adjusted means were compared using the Tukey test. Qualitative variables receptivity of the stigma and fruiting percentage were examined using a non-parametric frequency comparison Chisquare test.

\section{Results}

\subsection{Climatic conditions}

Climate varied between the two crop seasons (Table 1). The first crop was grown from late fall to early winter, when temperatures are lower and there is less sunlight than in the spring, when the second trial was run.

Table 1. Climatic data collected from the Dracena experimental station during the period of flowering and fruit production of zucchini squash during the fall/winter and spring crop seasons in 2019.

\begin{tabular}{|c|c|c|c|c|c|c|c|c|}
\hline \multirow{2}{*}{ Season } & \multicolumn{3}{|c|}{ Air temperature $\left({ }^{\circ} \mathrm{C}\right)$} & \multicolumn{3}{|c|}{ Relative humidity (\%) } & \multirow{2}{*}{$\mathrm{SR}(\mathrm{MJ} / \mathrm{m} 2$. day $)$} & \multirow{2}{*}{$\begin{array}{c}\text { ETo } \\
\text { (mm/day) }\end{array}$} \\
\hline & $\overline{\text { Mean }}$ & Maximum & Minimum & Mean & Maximum & Minimum & & \\
\hline Fall/Winter & 21.9 & 29.4 & 15.8 & 59.6 & 81.8 & 34.5 & 10.1 & 3.1 \\
\hline Spring & 27.6 & 35.0 & 21.5 & 60.7 & 85.3 & 34.8 & 13.5 & 4.7 \\
\hline
\end{tabular}

SR: Solar Radiation

ETo: Reference evapotranspiration

Source: Authors.

\subsection{Floral biology}

In the first planting, flowering began June 6 and lasted until July 21, totaling 46 days of flowering by the zucchini plants. Both staminate and pistillate flowers were produced from the first day of flowering. In the spring, flowering began October 14 and lasted until November 25, for a total of 43 days. The relative frequency of pistillate flowers was greater in the fall/winter season, than in the spring season. During both crop seasons, the plants produced more staminate than pistillate flowers, at ratios of 1.17:1 and 1.72:1 in the Fall/Winter and Spring crop seasons, respectively $(\mathrm{P}<0.001)$.

Anthesis began at about 03:40 during both crop seasons. The duration was about an hour shorter in the spring (7h09min), compared to the fall/winter (6h20min). Anthesis was not significantly different between the hand pollinated and bee pollinated greenhouses during the two crop seasons.

The staminate zucchini flowers produced a mean of 31,355 pollen grains, with no significant differences between the bee pollinated and hand pollinated greenhouse plants $(\mathrm{P}>0.20)$ and between the two seasons $(\mathrm{P}=0.115)$.

Pollen viability differed between seasons (Table 2). In the fall/winter season, pollen viability was similar at 8:00 and 12:00. In the spring, pollen viability decreased from 8:00 to 12:00. 
Table 2. Viability in $\%$ of pollen grains obtained from zucchini squash staminate flowers sampled at two different times in fall/winter and spring, 2019.

\begin{tabular}{ccccc}
\hline \multirow{2}{*}{ Time } & \multicolumn{2}{c}{ Seasons $(\%)$} & & Probability \\
\cline { 2 - 3 } & Fall/Winter & Spring & & Season x Time \\
\hline $08: 00$ & $97.75^{1} \mathrm{Aa}$ & $91.09 \mathrm{Ba}$ & 0.734 & 0.001 \\
\hline
\end{tabular}

${ }^{1}$ Means followed by the same capital letters in the rows and lower case letters in a column are not significantly different (Tukey test at $5 \%$ significance).

Source: Authors.

The effects of time of day and season on stigma receptivity were measured (Table 3 ). The strong bubbling of the hydroxide peroxide applied to the stigmas in both bee pollinated and hand pollinated greenhouses at 08:00 indicated a high degree of pollen receptivity. At 12:00, even though the flowers had already wilted, there was still some bubbling, indicating that the stigmas were still somewhat receptive. Stigma receptivity was greater in the spring than in the fall/winter season.

Table 3. Receptivity of the stigma obtained from zucchini squash pistillate flowers sampled at two different times in fall/winter and spring, 2019.

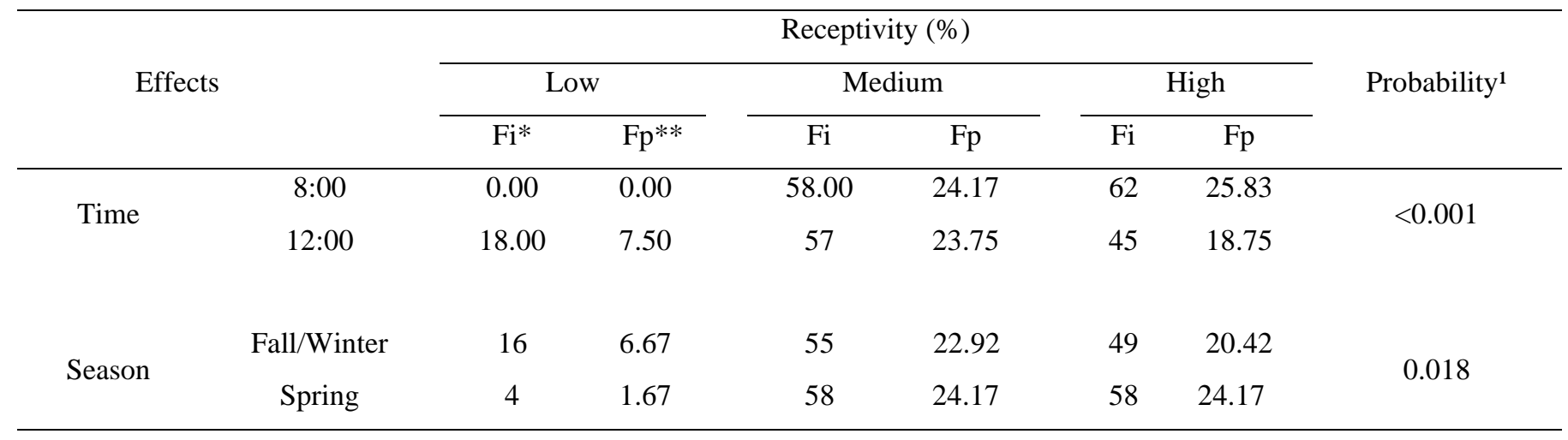

${ }^{1}$ Chi-Square test

*Fi: absolute frequency.

**Fp: relative frequency.

Source: Authors.

\subsection{Foraging behavior of honey bees on zucchini squash}

During fall/winter, the bees visited the flowers from the time the hive entrance to the greenhouse was opened (Fig. 2A). Visitation was most intensive between 08:00 and 11:00, with a mean of 42 bee visits to each pistillate flower. From 11:00 to $12: 00$, the flower visits were considerably reduced, because the flowers had already wilted, and the bees no longer had access. 
Figure 2. Mean number $( \pm \mathrm{SE})$ of bee visits to each pistillate zucchini flower during hour intervals in a greenhouse in fall/winter (A) and spring seasons (B).
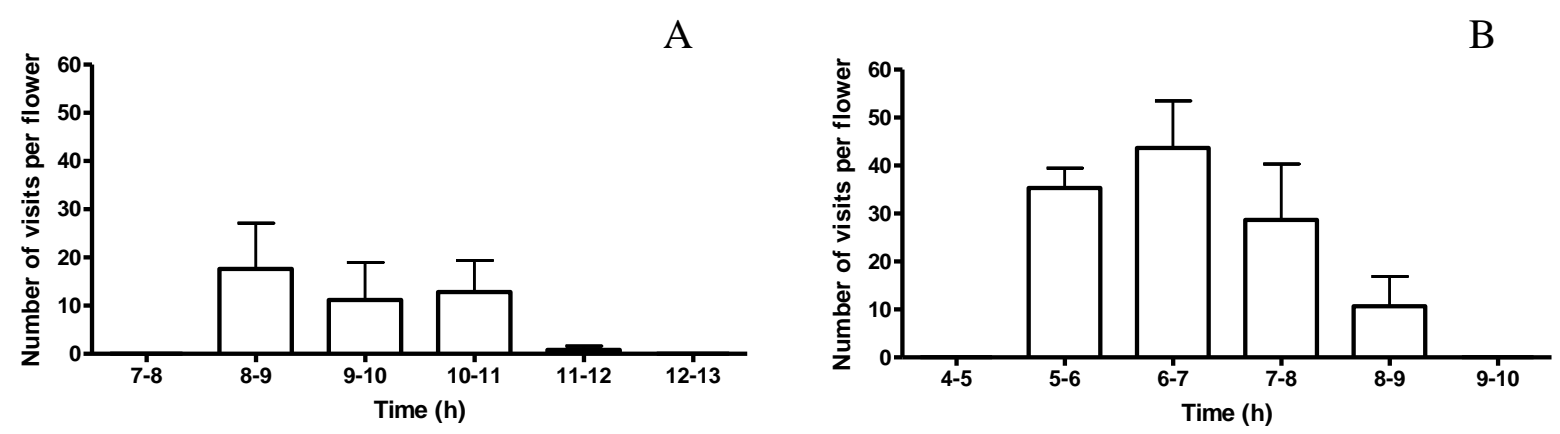

Source: Authors.

In the spring, the bees visited the flowers in the greenhouse beginning just after dawn, at first sunlight, since the entrance to the crop was open at 05:00 (Fig. 2B). The peak of visitation was observed from 06:00 to 07:00. After 08:00, flower visits decreased and by 09:00, the bees no longer went to the flowers. By that time, the flowers began to wilt and became less attractive and eventually were no longer available to the bees because they had closed.

There were more bee visits to pistillate flowers in the spring, with a mean of 118 visits per flower. In the spring, the bees had access to the flowers during five hours of anthesis. In the fall/winter crop season experiment, the time interval that the bees had available to visit the zucchini flowers was four hours.

\subsection{Fruit production}

During both seasons, no fruit was produced without pollination by either bees or manually. Fruit production was affected by season and pollination option (Table 4). In the spring, there was a greater percentage of fruit production per flower than in fall/winter. Pollinated flowers (both manually and by bees) resulted in a mean of $90 \%$ fruit production. Fruit production increased with increasing numbers of bee visits to pistillate flowers (Table 4).

Table 4. Fruiting percentage of zucchini squash in greenhouses from flowers that received 2, 4 or 8 bee visits $(2 \mathrm{v}, 4 \mathrm{v}$ and $8 \mathrm{v})$ or were freely visited (Fv) by honey bees or hand (manually) pollinated (Mp), in fall/winter and spring, 2019. Twenty flowers and the resulting fruits from these flowers were assayed for each pollination treatment for each season.

\begin{tabular}{cccccc}
\hline \multirow{2}{*}{ Effects } & & \multicolumn{2}{c}{ Fruiting percentage (\%) } & \multirow{2}{*}{$\begin{array}{c}\text { Overall } \\
\text { probability }\end{array}$} \\
\cline { 3 - 5 } & & $\mathrm{Fi}^{*}$ & $\mathrm{Fp}$ & Total & $<0.001$ \\
\hline \multirow{2}{*}{ Season } & Fall/Winter & 52.0 & $52.0^{1} \mathrm{~b}$ & 100 & \\
& Spring & 82.0 & $82.0 \mathrm{a}$ & 100 & $<0.001$ \\
\multirow{3}{*}{ Pollination } & $2 \mathrm{v}$ & 9.0 & $22.5 \mathrm{C}$ & 40 & \\
treatment & $4 \mathrm{v}$ & 21.0 & $52.5 \mathrm{~B}$ & 40 & 40 \\
& $8 \mathrm{v}$ & 32.0 & $80.0 \mathrm{~A}$ & 40 & \\
& $\mathrm{Fv}$ & 36.0 & $90.0 \mathrm{~A}$ & 40 & \\
& $\mathrm{Mp}$ & 36.0 & $90.0 \mathrm{~A}$ &
\end{tabular}

${ }^{1}$ Means followed by the same lower letters for season and capital letters for pollination treatment in a column are not significantly different (Chi-Square test at $5 \%$ significance).

*Fi: absolute frequency.

**Fp: relative frequency.

Source: Authors. 
During both crop seasons, at eight bee visits per flower and for flowers freely visited by bees, the fruits were significantly larger than with hand pollination (Table 5). Also, fruit weight increased with the number of flower visits.

Table 5. Fruit weight of zucchini squash in greenhouses from not pollinated flowers $(\mathrm{Np})$, or those that received 2 , 4 or 8 bee visits $(2 v, 4 v$ and $8 v)$ or were freely visited (Fv) by honey bees or hand (manually) pollinated (Mp), in fall/winter, 2019.

\begin{tabular}{ccccc}
\hline \multirow{2}{*}{ Pollination treatment } & \multicolumn{2}{c}{ Fruit weight $(\mathrm{g})$} & & Probability \\
\cline { 2 - 3 } & Fall/Winter & Spring & & Season x pollination \\
\hline $2 \mathrm{v}$ & $211.82^{1} \mathrm{Ac}$ & $118.77 \mathrm{Bd}$ & \\
& $271.39 \mathrm{Ab}$ & $200.89 \mathrm{Bc}$ & $<0.001$ \\
$8 \mathrm{v}$ & $312.05 \mathrm{Aa}$ & $323.44 \mathrm{Aa}$ & 5.319 & \\
Fv & $319.46 \mathrm{Ba}$ & $335.10 \mathrm{Aa}$ & \\
Mp & $226.40 \mathrm{Ac}$ & $238.24 \mathrm{Ab}$ & \\
\hline
\end{tabular}

${ }^{1}$ Means followed by the same capital letters on the lines and lower-case letters in a column are not significantly different (Tukey test at 5\% significance).

Source: Authors.

3.5 Mean time needed for hand pollination and for manipulating the hive entrances to direct bees to forage inside or outside the greenhouse

The mean time per day needed for hand pollination was approximately five to seven times greater than that needed to manipulate the hive entrances to allow bee pollination, depending on the season (Table 6). Mean time for hand pollination per flower was 26.4 seconds in fall/winter and 20.2 seconds in spring.

The total labor time needed to for beehive manipulations was 1.2 hours for both seasons and 8.7 and 6.3 hours for hand pollination in fall/winter and spring, respectively for the $100 \mathrm{~m}^{2}$ greenhouses.

Table 6. Labor time (s) for zucchini squash pollination in greenhouses with hand or honey bee pollination (mean time per day) in fall/winter and spring, 2019.

Labor time (s)

\begin{tabular}{lcccc}
\hline & \multicolumn{2}{c}{ Season } & \multicolumn{2}{c}{ Probability } \\
\cline { 2 - 3 } & Fall/Winter & Spring & Season x treatment \\
\cline { 2 - 5 } Bee pollination & $93.33^{1} \mathrm{Ab}$ & $93.42 \mathrm{Ab}$ & 0.962 & $\mathrm{P}<0.001$ \\
Hand Pollination & $677.67 \mathrm{Aa}$ & $492.58 \mathrm{Ba}$ & 19.157 & \\
\hline
\end{tabular}

${ }^{1}$ Means followed by the same capital letters on the lines and lower-case letters in a column are not significantly different (Tukey test at 5\% significance).

Source: Authors.

\subsection{Costs involved}

The mean total harvest, averaging the productions in the two crop seasons was $296.3 \mathrm{~kg}$ in the bee pollinated greenhouses, which was $41 \%$ greater than that obtained with hand pollination $(210.0 \mathrm{~kg})$. The market price was US\$0.45/kg for zucchini squash, giving a gross income of US\$133.96 per $100 \mathrm{~m}^{2}$ greenhouse with bee pollination and US\$94.92 with hand pollination.

The mean production cost except for pollination was calculated based on the mean cost per hectare for zucchini squash (Emater-DF, 2019), which translates to a mean cost of US $\$ 23.11$ for the $100 \mathrm{~m}^{2}$ area of the greenhouse (Table 7). 
Taking into consideration the hive rental and labor costs, the total cost was US $\$ 33.84$ for the greenhouse with bees and US\$33.71 for the greenhouse that required manual pollination. Consequently, the net profit for each $100 \mathrm{~m}^{2}$ greenhouse was US\$100.12 and US\$61.21 for the greenhouses with and without bees, respectively.

Table 7. Cost and profit estimates (converted to US\$) for production of zucchini squash in greenhouses with hand or honey bee pollination in fall/winter and spring, 2019.

\begin{tabular}{lcccc}
\hline \multicolumn{1}{c}{ Item } & \multicolumn{2}{c}{ Fall / Winter (US\$) } & \multicolumn{2}{c}{ Spring (US\$) } \\
\hline Labor cost ${ }^{1}$ & Bee pollination & Hand pollination & Bee pollination & Hand pollination \\
Hive rental & 1.69 & 12.29 & 1.69 & 8.90 \\
Production costs $/\left(100 \mathrm{~m}^{2}\right)^{*}$ & 9.04 & - & 9.04 & - \\
Total cost & 23.11 & 23.11 & 23.11 & 23.11 \\
Gross income & 33.84 & 35.40 & 33.84 & 32.01 \\
Operational profit & 130.78 & 92.50 & 137.14 & 97.34 \\
Profit/gross income $(\%)$ & 96.94 & 57.10 & 103.30 & 65.33 \\
\hline
\end{tabular}

${ }^{1} 1.2$ hours for bee pollination (both seasons); 8.7 hours for hand pollination (fall/winter) and 6.3 hours (spring).

2 fruit production for each season and respective price paid to the producer.

*Adapted from Emater-DF, 2019.

Source: Authors.

\section{Discussion}

The variables inherent to floral biology are intrinsically determined by the plants and are influenced by their environment (Öpik \& Rolfe 2005). Even within the same farm or field, due to edaphological heterogeneity, variations in the number and size of pollen grains occur (Lau et al., 1995). In our study, we were able to control soil fertility, fertilizer application, irrigation and pest control measures so that there were no differences in these parameters between the greenhouses during each of the two crop seasons.

Climate affected the plants and they responded differently in the two seasons, which allowed us to test the effect of hand and bee pollination under different temperature and solar radiation conditions. During the fall/winter crop season, mean temperatures and solar radiation were significantly reduced compared to the spring crop season.

During both seasons, there were more staminate than pistillate flowers. This predominance of staminate flowers is typical for many cucurbits, including C. pepo (Couto et al., 1990; Lattaro \& Malerbo-Souza 2006). The cooler and shorter days during the fall/winter crop season could be the reasons for increased production of pistillate flowers, similar to what was found in previous studies (Nicodemo et al., 2007; Oliveira et al., 2010). However, though there were more pistillate flowers in fall/winter than in spring, they were less receptive to pollen, based on the hydrogen peroxide receptivity assay.

Anthesis can be influenced by variations in temperature, humidity and photoperiod (Free, 1993; Nepi \& Pacini 1993). In our study, anthesis began at about the same time in the fall/winter and spring crop seasons; however, in the spring it was an hour shorter due to the higher temperatures, increased solar radiation and increased evapotranspiration. For some squash species, such as C. pepo, C. moschata and C. maxima, in different regions, anthesis begins from 03:00 to 06:00 and ends at from 10:00 to 14:00 (Nicodemo et al., 2007; Mélo et al., 2010).

Since squash plants are essentially dependent on insect pollinators for fruit production (McGregor, 1976; Gianinni et al., 2015), it is expected that the staminate flowers will produce large numbers of pollen grains. Vidal et al. (2006), in an open field study, reported 43,669 $\pm 1,382$ pollen grains in C. pepo staminate flowers. Variations for the same species can occur due 
to differences in variety and growing conditions. In our study, the pollen production did not differ between the two seasons, possibly because these were greenhouse instead of open field conditions.

High degrees of pollen viability and stigma receptivity are expected during early anthesis, tending to decrease as the flowers are close to wilting (Nepi \& Pacini 1993; Nicodemo et al., 2007; Bomfim et al., 2013). In our study, in the fall/winter season, pollen viability remained high until noon, though in spring it was reduced significantly by 12:00. The lowest values observed, at 12:00 in the spring, are still considered adequate for pollination and fruit formation (Pacini et al., 1997).

The bees efficiently pollinated the zucchini squash flowers within the greenhouse during the time that they had access, as they did in a similar experiment with greenhouse cucumbers (Nicodemo et al., 2018). These bees are effective pollinators of squash because of the high visit frequency to the flowers, from early morning until the flowers wither; they are also quite efficient at transferring pollen to the stigmas (Lattaro \& Malerbo-Souza 2006; Nicodemo et al., 2009; Vidal et al., 2010; Nerson, 2015; Rosmiati et al., 2015).

When honey bees collect nectar from staminate flowers, they contact the stamens and pollen adheres to their bodies; thus they become covered in pollen grains. When they collect nectar from the female flowers, they come into contact with the stigma, and transfer the pollen, effectively resulting in pollination (Lattaro \& Malerbo-Souza 2006). This behavior was also observed by Serra \& Campos (2010), who observed nectar collection from C. moschata flowers.

Vidal et al. (2010) reported that C. pepo flowers that received at least 12 visits by A. mellifera resulted in $100 \%$ fruitification. In our study, during the fall/winter crop season, the maximum percentage of fruit formation was $80 \%$, for flowers continuously open to bee visits and for manual pollination. In the Spring, fruit production was maximized (at $100 \%$ ) by at least eight bee visits and by manual pollination. The lower fruit set in fall/winter compared to spring, with the same number of bee visits, could be due to the lower receptivity of the stigma of the flowers that we observed.

Considering fruit weight, eight bee visits were sufficient to obtain fruit with commercially adequate weight. More than eight visits did not increase resultant fruit weight. Hand pollination and only four bee visits per flower resulted in smaller fruit, reducing income from zucchini squash production.

In the field, insect visits can be inhibited by rain or strong winds, or if there are no bees nesting nearby (Fischer et al., 2012). During rainy days, we noted that the bees continued to forage and pollinate inside the greenhouse.

Confining bees inside a greenhouse stresses the colony, which can try to abscond, in an effort to escape the heat and the lack of adequate food resources (Vyas \& Plunkett, 2019). When the two-entrance hives were used, some bees could be seen hitting the overhead plastic in the morning; however, in the afternoon, bees were no longer observed inside the greenhouse, which is useful since it facilitates crop management without exposing people to the bees or bees to direct applications of pesticides. Access to the outside during part of the day allowed the bees to collect water and food from the field. Consequently, the bee colonies in the two-entrance hives did not become weakened and continued to perform pollination services till the end of the flowering period. Additionally, the hives were not overheated by the conditions within the greenhouse and were returned to the beekeeper or apiary in good condition.

The use of bees in protected environments to pollinate crops has been increasing, as it can increase agricultural production with low-cost inputs (Cruz \& Campos 2009). Nicodemo et al. (2018), in a study of the use of two entrance hives to pollinate greenhouse cucumbers, found that the bees quickly adapted to directing foraging to inside and outside the greenhouse at predetermined times. Also, it was found that giving the bees access to the crop for four hours per day was sufficient to produce satisfactory levels of fruit production.

In our analysis, we found an increase of over $58.1 \%$ in operational profits by using bees instead of manual pollination for zucchini squash production, providing a final additional profit of 12-20\%. As the rental and manipulation of the hives has a fixed cost for each greenhouse, while labor costs for hand pollination are proportional to the greenhouse size, this profit margin 
would be increased if the greenhouses were larger than the 100 square meter greenhouses we used for this study, which is quite likely for commercial production units.

Considering that the number of bee visits to flowers was more than five times the number found to be adequate for maximum fruit weight and production, a single hive would be expected to be able to pollinate the plants in a much larger greenhouse. This would greatly increase the cost advantage over hand pollination.

In a similar comparison for passion fruit production, using bees (in this case a specialized native species) for pollination is more profitable than manual pollination (Vieira et al., 2010; Yamamoto et al., 2012). It considerably reduces the time needed and the farmer can avoid the cost to hire extra labor just for pollination.

Hand pollination is necessary for plant breeding in order to make controlled crosses to produce superior varieties (Romano et al., 2008). It is also an option for commercial production because the grower can produce without needing to manage or rent bees. However, considering labor costs and fruit production and quality, bee pollination is normally a much better option for production, as we have shown here for greenhouse zucchinis in Brazil.

Even if the farmer does the hand pollination himself, the time employed would probably be better invested in other activities. Another factor to be considered is the ergonomy of the work involved, since hand pollination will require postures that can provoke back problems that may reduce his work capacity for other activities (Jafry and O'Neill 2000). Incorporating bees as part of agricultural production should always be considered since it is a sustainable strategy, with economic, social and ecological benefits (Kevan et al. 1990).

This two-entrance hive system for greenhouse pollination should be investigated with other crops. Research would include a determination of optimum timing for confining bees to the greenhouse to ensure maximum pollination efficiency and fruit production, while minimizing negative impacts on the bee colonies.

\section{Conclusion}

The two-entrance hive system shown here facilitates management of bee activity, without the need for beekeeping experience or protective beekeeping equipment. Pollination of zucchini squash in greenhouses by honey bees kept in twoentrance hives was found to be economically viable and results in better quality and larger fruits and increased profits for the grower, when compared to hand pollination.

\section{Acknowledgments}

We thank the São Paulo Research Foundation (FAPESP) for the scholarship and other support (proc. 2018/25278-5).

\section{References}

Adams C. R., Bamford, K. M. \& Early M. P. (2008). Principles of Horticulture. Butterworth-Heinemann.

Alexander, M. P. (1969). Differential staining of aborted and non-aborted pollen. Stain Technology 44:117-122.

Allsopp, M. H., Lange, W.J., \& Veldtman, R. (2008). Valuing insect pollination services with cost of replacement. PLoS One 3:e3128.

Bomfim, I. G. A., Cruz, D. O., Freitas, B. M., \& Aragão, F. A. Z. (2013). Polinização em melancia com e sem semente. Embrapa.

Cardoso, A. I. I. (2005). Polinização manual em abobrinha: efeitos nas produções de frutos e de sementes. Horticultura Brasileira 23:731-734. https://doi.org/10.1590/S0102-05362005000300008

Couto, M. R. M., Lucio, A. D., Lopes, S. J., \& Carpes, R. H. (2009). Transformações de dados em experimentos com abobrinha italiana em ambiente protegido. Ciência Rural 39:1701-1707. https://doi.org/10.1590/S0103-84782009005000110

Couto, R. H. N., Pereira, J. M. S., \& Couto, L.A. (1990). Estudo da polinização entomófila em Cucurbita pepo (abóbora italiana). Científica $18: 21-27$.

Cruz, D. O., \& Campos, L. A. O. (2009). Polinização por abelhas em cultivos protegidos. Revista Brasileira de Agrociência 15:5-10. 
D’avila, M. D., \& Marchini, L. C. (2005). Polinização realizada por abelhas em culturas de importância econômica no Brasil. Boletim de Indústria Animal 62:79-90.

Decker, D. S. (1988). Origin(s), evolution, and systematics of Cucurbita pepo (Cucurbitaceae). Economic Botany 42:4-15.

Delaplane, K. S., Dag, A., Danka, R. G., Freitas, B. M., Garibaldi, L. A., Goodwin, R. M., \& Hormaza, J. I. (2013). Standard methods for pollination research with Apis mellifera. Journal of Apicultural Research 52:1-28. 10.3896/IBRA.1.52.4.12.

Emater (2019). Custo de produção da abóbora italiana. <http://www.emater.df.gov.br/wp-content/uploads/2019/07/Ab\%C3\%B3bora-it\%C3\%A1liana-1.pdf>

Fischer, S. Z., Barbieri, R. L., Stumpf, E. R. T., Peil, R. M. N., \& Schwenger, J. E. (2012). Cultivo e uso de abóboras ornamentais. Embrapa, Pelotas.

Free, J. B. (1993). Insect pollination of crops. Academic Press, London.

Giannini, T. C., Cordeiro, G. D., Freitas, B. M., Saraiva, A. M., \& Imperatriz-Fonseca, V. L. (2015). The dependence of crops for pollinators and the economic value of pollination in Brazil. Journal of Economic Entomology 108:849-857.

Hill, R., Nates-Parra, G., Quezada-Euán, J. J. G., Buchori, D., LeBuhn, G., Maués, M. M., Pert, P. L., Kwapong, P. K., Saeed, S., Breslow, S. J., Cunha, M. C., Dicks, L. V., Galetto, L., Gikungu, M., Howlett, B. G., Imperatriz-Fonseca, V. L., Lyver, P. B., Martín-López, B., Oteros-Rozas, E., Potts, S. G., \& Roué, M. (2019). Biocultural approaches to pollinator conservation. Nature Sustainability 2: 214-222.

Jafry, T., \& O'Neill, D. H. (2000). The application of ergonomics in rural development: a review. Applied ergonomics 31:263-268.

Kevan, P. G., Clark, E. A., \& Thomas, V. G. (1990). Insect pollinators and sustainable agriculture. American Journal of Alternative Agriculture 5:13-22.

King, J. R. (1960). The peroxidase reaction as an indicator of pollen viability. Stain Technology 36:225-227.

Lattaro, L. H., \& Malerbo-Souza, D. T. (2006). Polinização entomófila em abóbora caipira, Cucurbita mixta (Curcubitaceae). Acta Scientiarum Agronomy 28:563-568.

Lau, T. C., Lu, X., \& Koide, R. T. (1995). Step effects of soil fertility and mycorrhizal infection on pollen production and pollen grain size of Cucurbita pepo (Cucurbitaceae). Plant Cell Environment 18:169-177.

Martin, N. B., Serra, R., Oliveira, M. D. M., Ângelo, J. A., \& Okawa, H. L. (1997). Sistema "CUSTAGRI": sistema integrado de custos agropecuários. Instituto de Economia Agrícola, São Paulo.

Matsunaga, M., Bemelmans, P. F., Toledo, P. E. N., Dulley, R. D., Okawa, H., \& Pedroso, I. A. (1976). Metodologia de custo utilizada pelo IEA. Agric São Paulo 23:23-39.

McGregor, S. E. (1976). Insect Pollination of Cultivated Crop Plants. US Department of Agriculture, Washington.

Mélo, D. B. M., Mendonça, A. B. M., Paulino, A. S., Santos, M. H., Souza, N. C. M., \& Freitas, B. M. (2010). Polinização da abóbora (Curcubita moschata D.): um estudo sobre a biologia floral e visitantes florais no município de Satuba-AL. Revista Científica do Ifal 1:47-57.

Nepi, M., \& Pacini, E. (1993). Pollination, pollen viability and pistil receptivity in Cucurbita pepo. Annals of Botany 72:527-536.

Nerson, H. (2015) Effects of pollen-load on fruit yield, seed production and germination in melons, cucumbers and squash. Journal of Horticultural Science and Biotechnology 84:560-566.

Nicodemo. D., Couto, R. H. N., Malheiros, E. B., \& De Jong, D. (2007). Biologia floral em moranga (Cucurbita maxima Duch. var. "Exposição”). Acta Scientiarum Agronomy 29: 611-616.

Nicodemo, D., Couto, R. H. N., Malheiros, E. B., \& De Jong, D. (2009). Honey bee as an effective pollinating agent of pumpkin. Scientia Agricola 66:476480 .

Nicodemo, D., Malheiros, E. B., De Jong D, \& Couto, R. H. N. (2018). Improved pollination efficiency and reduced honey bee colony decline in greenhouses by allowing access to the outside during part of the day. Sociobiology 65:714-721. https://doi.org/10.13102/sociobiology.v65i4.3455.

Oliveira, N. L. C., Puiatti, M., Cecon, P. R., \& Bhering, A. S. (2010). Comportamento floral da abobrinha italiana em função da temperatura do ar. Horticultura Brasileira 28:827-834.

Öpik, H., \& Rolfe, S. (2005). The physiology of flowering plants. Cambridge University Press Cambridge.

Pacini, E., Franchi, G. G., Lisci, M., \& Nepi. M. (1997). Pollen viability related to type of pollination in six angiosperm species. Annals of Botany 80:83-87. https://doi.org/10.1006/anbo.1997.0421

Pfister, S. C., Eckerter, P.W., Schirmel, J., Cresswell, J. E., \& Entling, M. H. (2017). Sensitivity of commercial pumpkin yield to potential decline among different groups of pollinating bees. Royal Society Open Science 4:170102.

Raij, B. V., Canterella, H., Quaggio, J. A., \& Furlani, A. M. C. (1996). Recomendações de adubação e calagem para o Estado de São Paulo. Instituto Agronômico, Campinas.

Romano, C. M., Stumpf, E. R. T., Barbieri, R.L., Bevilaqua, G. A. P., \& Rodrigues, W. F. (2008). Polinização manual em abóboras. Embrapa, Pelotas. 
Rosmiati, M., Putra, R. E., \& Ruswandi, A. (2015). Insects pollination of zucchini farming in Indonesia and their economic importance. Asian Journal of Plant Science 14:84-88.

Rouphael, Y., Colla, G., Battistelli, A., Moscatello, S., Proietti, S., \& Rea, E. (2004). Yield, water requirement, nutrient uptake and fruit quality of zucchini squash grown in soil and closed soilless culture. Journal of Horticultural Science and Biotechnology 79:423-430.

SAS Institute (2020) SAS® OnDemand. Version 9.4. SAS Inst Inc, Cary.

Serra, B. D. V., \& Campos, L. A. O. (2010). Polinização entomófila de abobrinha, Cucurbita moschata (Cucurbitaceae). Neotropical Entomology 39:153-159.

Stone, J. L., Thomson, J. D., \& Dent-Acosta, S. J. (1995). Assessment of pollen viability in hand-pollination experiments: a review. American Journal of Botany 82:1186-1197.

van Straten, G., van Henten, E. J., van Willigenburg, L. G., \& van Ooteghem, R. J. C. (2010). Optimal control of greenhouse cultivation. CRC Press, Boca Raton.

Vidal, M. G., De Jong, D., Wien, H. C., \& Morse, R. A. (2006). Produção de néctar e pólen em abóbora (Cucurbita pepo L.). Revista Brasileira de Botânica 29:267-273.

Vidal, M. G., De Jong, D., Wien, H. C., \& Morse, R. A. (2010). Pollination and fruit set in pumpkin (Cucurbita pepo) by honey bees. Revista Brasileira de Botânica 33:106-113.

Vieira, P. F. S. P., Cruz, D. O., Gomes, M. F.M., Campos, L. A. O., \& Lima, J. E. (2010). Valor econômico da polinização por abelhas mamangavas no cultivo do maracujá-amarelo. Revista Iberoamericana de Economia Ecológica 15:43-53.

Vyas, N. B., \& Plunkett, A. D. (2019). Description of disparate responses of two indoor feral bee colonies. Bee World 96:12-15.

Whitaker, T. W., \& Bemis, W. P. (1975). Origin and evolution of the cultivated Cucurbita. Bulletin of the Torrey Botanical Club 102:362-368.

Yamamoto, M., Silva, C. I., Augusto, S. C., Barbosa, A. A. A., \& Oliveira, P. E. (2012). The role of bee diversity in pollination and fruit set of yellow passion fruit (Passiflora edulis forma flavicarpa, Passifloraceae) crop in Central Brazil. Apidologie 43:515-526. 